\title{
Lauraceae Along an Altitudinal Gradient in Southern Brazil
}

\author{
Marcelo Leandro Brotto ${ }^{1}$ (D), Eduardo Damasceno Lozano $^{2}$ (D), \\ Felipe Eduardo Cordeiro Marinero ${ }^{2}$ (D), Alexandre Uhlmann ${ }^{3}$ (1), \\ Christopher Thomas Blum ${ }^{2}$ (D), Carlos Vellozo Roderjan² (1) \\ ${ }^{1}$ Prefeitura Municipal de Curitiba, Curitiba, PR, Brasil \\ ${ }^{2}$ Universidade Federal do Paraná (UFPR), Curitiba, PR, Brasil \\ ${ }^{3}$ Embrapa Pesca e Aquicultura, Palmas, TO, Brasil
}

\begin{abstract}
We performed a phytosociological study on an altitudinal gradient in Lauráceas State Park (Parque Estadual das Lauráceas/PR), aiming to describe the Montane Atlantic Rain Forest, to verify the importance of Lauraceae, and to evaluate the communities' successional stage. We distributed survey units $\left(2,000 \mathrm{~m}^{2}\right.$ quadrats $)$ along an altitudinal gradient and surveyed all individuals with $\mathrm{DBH} \geq 10 \mathrm{~cm}$, which composed the arboreal component. In smaller quadrats $\left(250 \mathrm{~m}^{2}\right)$, we surveyed regeneration individuals. The community at 800 and $900 \mathrm{~m}$ a.s.l. shows typical characteristics of Montane forest in an advanced successional stage, and the abundance of Ocotea catharinensis is its main indicator. At 1,000 and 1,100 m a.s.l., the forest is characterized as Montane with short stature in an advanced successional stage, with the occurrence of typical upper montane species such as $O$. porosa and $O$. vaccinioides.
\end{abstract}

Keywords: Atlantic forest, Lauráceas State Park, phytosociology. 


\section{INTRODUCTION AND OBJECTIVES}

The eastern portion of the Paraná State has currently the largest extension of forests and conservation units of integral protection in the state. Among the largest areas, the Lauráceas State Park (Parque Estadual das Lauráceas - PEL) harbors an important area of the Atlantic Rain Forest (ARF, or Dense Ombrophilous Forest - DOF, in the Brazilian classification system). The name of this conservation unit refers to the high frequency of trees from Lauraceae family, popularly called "canelas" (Paraná, 2002).

Studies have shown that this family is one of the major botanical families in the Atlantic Rain Forest domain in Paraná, either in number of individuals or in species richness, sharing this dominance with Fabaceae, Melastomataceae, Myrtaceae, and Rubiaceae (Oliveira-Filho \& Fontes, 2000; Scheer \& Blum, 2011).

According to Klein (1984), who studied the ARF in southern Brazil with Veloso, a slow succession tending to form the association named as Ocotietum was noted among almost all plant communities. In this successional stage, Ocotea catharinensis Mez has marked dominance in the forest structure, which seems to be the most evolved stage of the forest succession and the best representation of the dynamic balance under the regional soil and the current climate conditions (Klein, 1984).

Despite the good conservation conditions of the ARF in eastern slope areas of "Serra do Mar" in Paraná, there are still few studies on its structure, on its floristic composition, and, mainly, on its differentiation along environmental gradients (Blum \& Roderjan, 2007).

Besides this, a large gap in knowledge is observed regarding the flora at $P E L$, even after 38 years of its creation. So far as we know, the only systematic study carried out in the PEL was the Rapid Ecological Assessment, a document that allows the preparation of Conservation Unit Management Plan (Paraná, 2002). Considering these scenarios, this study primarily aimed to describe the structure and the floristic composition of a Montane ARF gradient in this Conservation Unit. As secondary objectives we sought: a) to verify whether Lauraceae was the most expressive family along the gradient; b) to evaluate the successional stage of the forest communities studied to contribute to reference information about these forest formations.

\section{MATERIALS AND METHODS}

The PEL occupies an area of 32,256 ha in part of the municipalities of Adrianópolis, Tunas do Paraná, and Bocaiúva do Sul, between the coordinates $24^{\circ} 40^{\prime} 44^{\prime \prime} \mathrm{S}-25^{\circ} 00^{\prime} 48^{\prime \prime} \mathrm{S}$ and $48^{\circ} 32^{\prime} 17^{\prime \prime} \mathrm{W}-48^{\circ} 44^{\prime} 29^{\prime \prime} \mathrm{W}$, at altimetric levels ranging between $100 \mathrm{~m}$ and $1,226 \mathrm{~m}$ a.s.l. Its vegetation cover is composed of ARF in its lowland ("Aluvial"), lower montane ("Submontana"), Montane ("Montana") and upper montane ("Altomontana") formations, with transition zones contact with Mixed Ombrophilous Forest (a typical temperate forest with Araucaria, which occupies the high plateaus of South and Southeastern regions of Brazil) and Rupicolous Vegetation at high altitude. Due to the great altimetric amplitude, the $P E L$ is under the influence of the $\mathrm{Cfa}$ and Cfb climate types according to Köppen's classification (Kottek et al., 2006), with the dominance of the $\mathrm{Cfb}$ climate type (Paraná, 2002).

The sampling system was composed of four conglomerates of 2,000 $\mathrm{m}^{2}$ each, systematically allocated at every $100 \mathrm{~m}$ altitudinal interval (altimetric zone A 1,100 $\mathrm{m}$ a.s.l., B - 1,000 $\mathrm{m}$ a.s.l., C - $900 \mathrm{~m}$ a.s.l., and D - $800 \mathrm{~m}$ a.s.l.). Each conglomerate was subdivided into ten $10 \times 20 \mathrm{~m}$ plots, forming a $20 \times 100 \mathrm{~m}$ rectangle. All trees with DBH (Diameter at Breast Height) $\geq 10 \mathrm{~cm}$ were surveyed and included in the arboreal component. Inside each sample plot subdivided, a smaller quadrat was allocated $(2.5 \times 10 \mathrm{~m})$ aiming at regeneration component sampling (saplings with $\mathrm{DBH} \geq 1$ ). In addition to the $\mathrm{DBH}$ and the taxonomic identification, crown diameter and total height were estimated with a hypsometer.

The conglomerates were allocated in places where the forest had approximately primary structure. Taxa identification was carried out by comparison with exsiccates in the Botanical Municipal Museum of Curitiba (MBM). The collected data were processed in the EXCEL program. The phytosociological parameters were calculated as described in Mueller-Dombois \& Ellenberg (1974), and the Shannon diversity index (H') according to Magurran (1988). The ecological group of the species was determined considering Vibrans et al. (2013), with adaptations based on Budowski (1965). For simple comparison with volume results obtained by Klein (1980), the model "stem with bark volume", adjusted by Vibrans et al. (2013, p.116) was used for "all species": 
$\ln (V f / 1000)=-17.753+0.979 \ln D B H^{2}+0.567 \ln h$, with $\mathrm{R}^{2}=0.98$ and $\mathrm{S}_{\mathrm{xy}}=2.19 \%$.

The evaluation of forest succession stage was carried out based on CONAMA Resolutions No. 2 (Brazil, 1994a) and No. 4 (Brazil, 1994b), and by comparison with other reference studies such as Klein $(1980,1984)$ and Vibrans et al. (2013), who also characterized Montane ARFs in southern Brazil.

\section{RESULTS AND DISCUSSION}

The sampling of the two compartments included 1,070 tree individuals, 15 of which included in the dead category, and four of them remaining taxonomically undetermined. The remaining individuals comprised 996 trees or saplings, 32 palm trees, and 23 fern trees. The floristic composition consisted of 46 families, 82 genera, and 143 species. The richest families were Lauraceae (29 spp.), Myrtaceae (23), Fabaceae (10), Melastomataceae (8), Rubiaceae (7), Monimiaceae (5), Aquifoliaceae, Arecaceae, and Primulaceae (4), with the first five accounting for $53.8 \%$ of the total number of species. Lauraceae exceeded Myrtaceae in only six species, with more than double the number of individuals
(258 vs. 124) representing almost a quarter of the total number of living trees (24.5\%) (Tables 1 and 2). The richest genera were Ocotea (15 spp.), Eugenia (11), Miconia (7), Myrcia (6), Mollinedia (5), Ilex, Myrsine, and Persea (4), and the first five genera accounting for $30.8 \%$ of the total of species. The predominant dispersion syndrome was zoochoric (123), followed by anemocoric (19) and autocoric (1).

Considering the four altitudinal zones as a whole and the two compartments of the forest $(\mathrm{DBH} \geq 1 \mathrm{~cm})$, the phytosociology computed a total density of 5,406 ind.ha ${ }^{-1}$ and an average dominance of $45.75 \mathrm{~m}^{2}$. $\mathrm{ha}^{-1}$. The five species with more individuals in both compartments were Alchornea triplinervia (Spreng.) Müll. Arg. (65), Psychotria suterella Müll. Arg. (58), Ocotea catharinensis $\mathrm{Mez}$ (50), Ouratea vaccinioides (A. St.-Hil. \& Tul.) Engl. (39) and Ocotea bicolor Vattimo-Gil (33), totaling $23.2 \%$ of all trees and saplings. In turn, the most representative families in abundance were Lauraceae (258), Myrtaceae (124), Rubiaceae (92), Euphorbiaceae (65), and Monimiaceae (60), which summed $56.8 \%$ of the total density. However, the high value of density of Euphorbiaceae is a result of high density of only one species (A. triplinervia).

Table 1. Summary of phytosociological parameters of the arboreal $(\mathrm{DBH} \geq 10 \mathrm{~cm})$ and regeneration $(10>\mathrm{DBH} \geq 1 \mathrm{~cm})$ compartments of the Montane Atlantic Rain Forest in Lauráceas State Park (10 species with the highest VI).

\begin{tabular}{|c|c|c|c|c|c|c|c|c|c|c|c|}
\hline \multirow{2}{*}{\begin{tabular}{|l} 
Arboreal \\
component
\end{tabular}} & \multirow[b]{2}{*}{ Vt } & \multirow[b]{2}{*}{ RCC } & \multirow[b]{2}{*}{ RDe } & \multirow[b]{2}{*}{ RDo } & \multirow[b]{2}{*}{ RF } & \multicolumn{6}{|c|}{ Sapling component } \\
\hline & & & & & & VI & Species & RDe & RDo & $\mathbf{R F}$ & VI \\
\hline $\begin{array}{l}\text { Ouratea } \\
\text { vaccinioides }\end{array}$ & 9.80 & 8.0 & 13.8 & 8.2 & 6.0 & 28.0 & $\begin{array}{c}\text { Ouratea } \\
\text { vaccinioides }\end{array}$ & 15.4 & 21.5 & 10.6 & 47.5 \\
\hline Ocotea bicolor & 9.75 & 10.0 & 10.5 & 8.8 & 6.8 & 26.1 & $\begin{array}{l}\text { Mollinedia } \\
\text { boracensis }\end{array}$ & 13.8 & 5.5 & 8.5 & 27.9 \\
\hline Ilex microdonta & 12.41 & 9.9 & 7.6 & 11.6 & 6.0 & 25.2 & $\begin{array}{l}\text { Guatteria } \\
\text { australis }\end{array}$ & 7.7 & 5.9 & 8.5 & 22.1 \\
\hline Ocotea porosa & 4.17 & 8.8 & 7.1 & 6.5 & 5.1 & 18.8 & $\begin{array}{l}\text { Ocotea } \\
\text { porosa }\end{array}$ & 4.6 & 11.3 & 4.3 & 20.2 \\
\hline $\begin{array}{l}\text { Ocotea } \\
\text { vaccinioides }\end{array}$ & 6.51 & 7.4 & 6.2 & 7.6 & 4.3 & 18.1 & $\begin{array}{c}\text { Miconia } \\
\text { pusilliflora }\end{array}$ & 6.2 & 5.5 & 8.5 & 20.1 \\
\hline Laplacea fruticosa & 5.72 & 4.6 & 4.8 & 4.1 & 4.3 & 13.1 & $\begin{array}{c}\text { Eugenia } \\
\text { melanogyna }\end{array}$ & 6.2 & 4.3 & 6.4 & 16.9 \\
\hline $\begin{array}{l}\text { Guatteria } \\
\text { australis }\end{array}$ & 2.89 & 4.9 & 3.3 & 3.2 & 6.0 & 12.5 & $\begin{array}{c}\text { Myrsine } \\
\text { gardneriana }\end{array}$ & 4.6 & 5.2 & 4.3 & 14.1 \\
\hline $\begin{array}{l}\text { Symplocos } \\
\text { glanduloso- } \\
\text { marginata }\end{array}$ & 6.17 & 7.9 & 3.3 & 6.6 & 2.6 & 12.5 & $\begin{array}{l}\text { Tibouchina } \\
\text { cf. pilosa }\end{array}$ & 3.1 & 8.2 & 2.1 & 13.4 \\
\hline Persea alba & 4.62 & 2.1 & 3.3 & 3.7 & 3.4 & 10.4 & $\begin{array}{l}\text { Myrcia } \\
\text { pulchra }\end{array}$ & 3.1 & 4.5 & 4.3 & 11.8 \\
\hline
\end{tabular}


Table 1. Continued...

\begin{tabular}{|c|c|c|c|c|c|c|c|c|c|c|c|}
\hline \multirow{2}{*}{$\begin{array}{l}\text { Arboreal } \\
\text { component }\end{array}$} & \multirow[b]{2}{*}{ Vt } & \multirow[b]{2}{*}{ RCC } & \multirow[b]{2}{*}{ RDe } & \multirow[b]{2}{*}{ RDo } & \multirow[b]{2}{*}{ RF } & \multirow[b]{2}{*}{ VI } & \multicolumn{5}{|c|}{ Sapling component } \\
\hline & & & & & & & Species & RDe & RDo & $\mathbf{R F}$ & VI \\
\hline Ocotea pulchella & 8.23 & 3.7 & 1.4 & 6.0 & 2.6 & 10.0 & Clusia criuva & 3.1 & 6.0 & 2.1 & 11.2 \\
\hline Subtotal zone A & 70.26 & 67.3 & 61.4 & 66.2 & 47.0 & 174.7 & $\begin{array}{c}\text { Subtotal } \\
\text { zone A }\end{array}$ & 67.7 & 78.0 & 59.6 & 205.2 \\
\hline $\begin{array}{l}\text { Alchornea } \\
\text { triplinervia }\end{array}$ & 18.93 & 13.3 & 26.0 & 14.0 & 10.5 & 50.5 & $\begin{array}{c}\text { Mollinedia } \\
\text { boracensis }\end{array}$ & 8.1 & 11.5 & 5.4 & 25.0 \\
\hline Sloanea lasiocoma & 34.29 & 4.3 & 1.5 & 18.7 & 2.1 & 22.3 & $\begin{array}{c}\text { Cabralea } \\
\text { canjerana }\end{array}$ & 8.1 & 5.7 & 7.6 & 21.4 \\
\hline Myrcia splendens & 3.56 & 4.6 & 6.9 & 2.4 & 8.4 & 17.7 & $\begin{array}{l}\text { Alchornea } \\
\text { triplinervia }\end{array}$ & 4.8 & 12.0 & 3.3 & 20.1 \\
\hline Persea willdenovii & 14.31 & 10.7 & 4.6 & 7.2 & 5.3 & 17.0 & $\begin{array}{c}\text { Ocotea } \\
\text { odorifera }\end{array}$ & 8.1 & 2.4 & 6.5 & 17.0 \\
\hline Ocotea odorifera & 6.37 & 7.4 & 5.3 & 5.4 & 5.3 & 16.0 & $\begin{array}{c}\text { Ocotea } \\
\text { nectandrifolia }\end{array}$ & 5.6 & 3.6 & 6.5 & 15.8 \\
\hline Ocotea bicolor & 2.95 & 5.5 & 4.6 & 6.0 & 4.2 & 14.8 & $\begin{array}{c}\text { Guatteria } \\
\text { australis }\end{array}$ & 6.5 & 1.6 & 5.4 & 13.5 \\
\hline $\begin{array}{l}\text { Psychotria } \\
\text { vellosiana }\end{array}$ & 5.71 & 4.6 & 5.3 & 3.9 & 4.2 & 13.5 & $\begin{array}{c}\text { Miconia } \\
\text { pusilliflora }\end{array}$ & 4.8 & 4.2 & 4.3 & 13.4 \\
\hline Pouteria bullata & 10.17 & 6.4 & 2.3 & 5.3 & 3.2 & 10.8 & $\begin{array}{l}\text { Byrsonima } \\
\text { ligustrifolia }\end{array}$ & 3.2 & 5.9 & 3.3 & 12.3 \\
\hline $\begin{array}{l}\text { Tachigali } \\
\text { denudata }\end{array}$ & 9.88 & 8.9 & 2.3 & 5.3 & 3.2 & 10.7 & $\begin{array}{c}\text { Pouteria } \\
\text { bullata }\end{array}$ & 4.8 & 3.3 & 3.3 & 11.4 \\
\hline Cyathea delgadii & 2.09 & 2.2 & 4.6 & 1.5 & 4.2 & 10.3 & $\begin{array}{l}\text { Miconia } \\
\text { sellowiana }\end{array}$ & 4.8 & 2.5 & 3.3 & 10.6 \\
\hline Subtotal zone B & 108.26 & 67.8 & 63.4 & 69.7 & 50.5 & 183.6 & $\begin{array}{c}\text { Subtotal } \\
\text { zone B }\end{array}$ & 58.9 & 52.8 & 48.9 & 160.5 \\
\hline $\begin{array}{l}\text { Ocotea } \\
\text { catharinensis }\end{array}$ & 119.00 & 31.9 & 12.3 & 29.3 & 7.0 & 48.6 & $\begin{array}{l}\text { Psychotria } \\
\text { suterella }\end{array}$ & 29.6 & 13.1 & 8.9 & 51.5 \\
\hline $\begin{array}{l}\text { Cryptocarya } \\
\text { aschersoniana }\end{array}$ & 55.87 & 15.0 & 7.7 & 13.3 & 7.0 & 28.0 & $\begin{array}{l}\text { Syagrus } \\
\text { hoehnei }\end{array}$ & 5.3 & 15.6 & 5.9 & 26.9 \\
\hline $\begin{array}{l}\text { Copaifera } \\
\text { trapezifolia }\end{array}$ & 30.44 & 6.7 & 5.4 & 6.9 & 6.0 & 18.3 & $\begin{array}{l}\text { Mollinedia } \\
\text { schottiana }\end{array}$ & 5.9 & 9.8 & 5.9 & 21.7 \\
\hline Pouteria bullata & 5.97 & 1.0 & 6.2 & 1.5 & 6.0 & 13.7 & $\begin{array}{c}\text { Ocotea } \\
\text { catharinensis }\end{array}$ & 8.3 & 4.7 & 4.0 & 16.9 \\
\hline $\begin{array}{l}\text { Calyptranthes } \\
\text { lucida }\end{array}$ & 4.98 & 3.9 & 5.4 & 1.7 & 6.0 & 13.1 & $\begin{array}{c}\text { Pouteria } \\
\text { bullata }\end{array}$ & 3.6 & 7.4 & 5.0 & 15.9 \\
\hline $\begin{array}{l}\text { Cabralea } \\
\text { canjerana }\end{array}$ & 13.73 & 1.5 & 1.5 & 7.2 & 2.0 & 10.7 & $\begin{array}{c}\text { Guatteria } \\
\text { australis }\end{array}$ & 2.4 & 4.4 & 4.0 & 10.7 \\
\hline Guapira opposita & 5.85 & 1.5 & 3.8 & 1.7 & 4.0 & 9.5 & $\begin{array}{c}\text { Mollinedia } \\
\text { elegans }\end{array}$ & 3.0 & 2.5 & 5.0 & 10.4 \\
\hline $\begin{array}{l}\text { Alchornea } \\
\text { triplinervia }\end{array}$ & 18.29 & 7.6 & 2.3 & 5.2 & 2.0 & 9.5 & $\begin{array}{c}\text { Eugenia } \\
\text { neoverrucosa }\end{array}$ & 3.6 & 1.8 & 5.0 & 10.3 \\
\hline $\begin{array}{l}\text { Matayba } \\
\text { intermedia }\end{array}$ & 5.13 & 2.0 & 3.1 & 1.7 & 4.0 & 8.8 & $\begin{array}{l}\text { Cordiera } \\
\text { concolor }\end{array}$ & 1.8 & 3.3 & 3.0 & 8.1 \\
\hline $\begin{array}{l}\text { Eugenia } \\
\text { copacabanensis }\end{array}$ & 9.53 & 2.1 & 2.3 & 3.5 & 2.0 & 7.9 & $\begin{array}{l}\text { Calyptranthes } \\
\text { lucida }\end{array}$ & 2.4 & 1.7 & 4.0 & 8.0 \\
\hline Subtotal zone C & 268.79 & 73.3 & 50.0 & 72.1 & 46.0 & 168.1 & $\begin{array}{c}\text { Subtotal } \\
\text { zone C }\end{array}$ & 65.7 & 64.3 & 50.5 & 180.4 \\
\hline
\end{tabular}


Table 1. Continued...

\begin{tabular}{|c|c|c|c|c|c|c|c|c|c|c|c|}
\hline \multirow{2}{*}{$\begin{array}{l}\text { Arboreal } \\
\text { component } \\
\text { Species } \\
\end{array}$} & \multirow[b]{2}{*}{ Vt } & \multirow[b]{2}{*}{ RCC } & \multirow[b]{2}{*}{ RDe } & \multirow[b]{2}{*}{ RDo } & \multirow[b]{2}{*}{ RF } & \multirow[b]{2}{*}{ VI } & \multicolumn{5}{|c|}{ Sapling component } \\
\hline & & & & & & & Species & RDe & RDo & RF & VI \\
\hline $\begin{array}{l}\text { Ocotea } \\
\text { catharinensis }\end{array}$ & 66.41 & 17.2 & 6.7 & 17.7 & 5.4 & 29.7 & $\begin{array}{c}\text { Guatteria } \\
\text { australis }\end{array}$ & 18.7 & 19.0 & 10.5 & 48.2 \\
\hline $\begin{array}{l}\text { Alchornea } \\
\text { triplinervia }\end{array}$ & 49.82 & 8.1 & 9.7 & 12.8 & 4.5 & 27.0 & $\begin{array}{c}\text { Euterpe } \\
\text { edulis }\end{array}$ & 7.5 & 10.2 & 6.6 & 24.3 \\
\hline $\begin{array}{l}\text { Aspidosperma } \\
\text { australe }\end{array}$ & 37.99 & 10.4 & 5.2 & 8.0 & 5.4 & 18.6 & $\begin{array}{l}\text { Geonoma } \\
\text { schottiana }\end{array}$ & 7.5 & 4.6 & 5.3 & 17.3 \\
\hline Protium kleinii & 34.20 & 5.7 & 3.7 & 7.6 & 3.6 & 14.9 & $\begin{array}{l}\text { Protium } \\
\text { kleinii }\end{array}$ & 8.4 & 2.0 & 6.6 & 17.0 \\
\hline $\begin{array}{l}\text { Cryptocarya } \\
\text { aschersoniana }\end{array}$ & 21.84 & 5.5 & 4.5 & 5.9 & 3.6 & 13.9 & $\begin{array}{c}\text { Garcinia } \\
\text { gardneriana }\end{array}$ & 1.9 & 8.9 & 2.6 & 13.4 \\
\hline Mollinedia uleana & 2.28 & 1.8 & 6.0 & 1.0 & 6.3 & 13.3 & $\begin{array}{l}\text { Cyathea } \\
\text { atrovirens }\end{array}$ & 4.7 & 2.7 & 5.3 & 12.7 \\
\hline $\begin{array}{l}\text { Eugenia } \\
\text { copacabanensis }\end{array}$ & 20.38 & 6.2 & 3.7 & 4.7 & 2.7 & 11.1 & $\begin{array}{c}\text { Andira } \\
\text { fraxinifolia }\end{array}$ & 4.7 & 4.0 & 3.9 & 12.7 \\
\hline Pouteria bullata & 11.70 & 2.9 & 3.0 & 2.9 & 3.6 & 9.5 & $\begin{array}{l}\text { Copaifera } \\
\text { trapezifolia }\end{array}$ & 1.9 & 3.9 & 2.6 & 8.4 \\
\hline $\begin{array}{l}\text { Psychotria } \\
\text { vellosiana }\end{array}$ & 7.77 & 1.9 & 2.2 & 3.2 & 2.7 & 8.1 & $\begin{array}{c}\text { Pterocarpus } \\
\text { rohrii }\end{array}$ & 2.8 & 2.9 & 2.6 & 8.3 \\
\hline $\begin{array}{l}\text { Cyathea } \\
\text { atrovirens }\end{array}$ & 1.23 & 0.3 & 3.7 & 0.6 & 3.6 & 7.9 & $\begin{array}{l}\text { Aiouea } \\
\text { saligna }\end{array}$ & 2.8 & 2.8 & 2.6 & 8.2 \\
\hline Subtotal zone D & 253.62 & 60.1 & 48.5 & 64.4 & 41.1 & 154.0 & $\begin{array}{c}\text { Subtotal } \\
\text { zone D }\end{array}$ & 60.7 & 61.0 & 48.7 & 170.4 \\
\hline
\end{tabular}

Vt: trunk volume with bark $\left(\mathrm{m}^{3} \cdot \mathrm{ha}^{-1}\right)$; RCC: relative canopy coverage; RDe: relative density; RDo: relative dominance; RF: relative frequency; VI: value of importance (0-300).

Table 2. Summary of phytosociological parameters of the $\mathrm{c} 1$ arboreal compartment $(\mathrm{DBH} \geq 10 \mathrm{~cm})$ and $\mathrm{c} 2$ regeneration compartment $(10>\mathrm{DBH} \geq 1 \mathrm{~cm})$ of the Montane Rain Forest in the Lauráceas State Park.

\begin{tabular}{|c|c|c|c|c|c|c|c|c|}
\hline Statistics / Zones & $\mathbf{A}$ & B & C & D & $\mathbf{A}$ & B & C & D \\
\hline & \multicolumn{4}{|c|}{ c1: H (m) } & \multicolumn{3}{|c|}{ cl: DBH (cm) } & \\
\hline Mean & 7.3 & 9.5 & 18.7 & 17.5 & 17.3 & 19.8 & 25.6 & 25.9 \\
\hline Standard deviation & 1.74 & 3.05 & 7.95 & 7.78 & 6.88 & 12.59 & 17.55 & 15.34 \\
\hline $\begin{array}{l}\text { Coefficient of } \\
\text { variation }\end{array}$ & 23.7 & 32.1 & 42.4 & 44.3 & 39.8 & 63.6 & 68.6 & 59.3 \\
\hline \multirow[t]{2}{*}{ Maximum } & 12.0 & 18.0 & 40.0 & 38.0 & 54.1 & 89.1 & 95.5 & 83.4 \\
\hline & \multicolumn{4}{|c|}{ cl: $g\left(m^{2}\right)$} & \multicolumn{3}{|c|}{ c2: $g\left(m^{2}\right)$} & \\
\hline Mean & 0.0272 & 0.0432 & 0.0754 & 0.0709 & 0.0018 & 0.0013 & 0.0012 & 0.0014 \\
\hline Standard deviation & 0.0275 & 0.0773 & 0.1191 & 0.0875 & 0.0020 & 0.0019 & 0.0016 & 0.0015 \\
\hline $\begin{array}{l}\text { Coefficient of } \\
\text { variation }\end{array}$ & 100.8 & 179.2 & 158.0 & 123.4 & 112.6 & 144.7 & 129.7 & 103.8 \\
\hline Maximum & 0.2300 & 0.6239 & 0.7162 & 0.5463 & 0.0076 & 0.0121 & 0.0075 & 0.0076 \\
\hline Total $\left(\mathrm{m}^{2} \cdot \mathrm{ha}^{-1}\right)$ & 29.43 & 29.99 & 50.14 & 47.87 & 4.70 & 6.59 & 8.21 & 6.05 \\
\hline $\mathrm{c} 1+\mathrm{c} 2\left(\mathrm{~m}^{2} \cdot \mathrm{ha}^{-1}\right)$ & & & & & 34.13 & 36.58 & 58.35 & 53.92 \\
\hline
\end{tabular}

H: total height; DBH: diameter at $1.30 \mathrm{~m}$; g: basal area. 
The vegetation in altimetric zone A has only one vertical stratum, where Ouratea vaccinioides, $O$. bicolor, Ilex microdonta Reissek, Ocotea porosa (Nees \& Mart.) Barroso, and Ocotea vaccinioides (Meisn.) Mez together accounted for more than a third of the VI. The three species with the highest relative canopy coverage were O. bicolor, I. microdonta, and O. porosa, totaling 28.6\%. (Table 1). Symplocos glanduloso-marginata Hoehne, O. bicolor, and Ocotea pulchella (Nees \& Mart.) Mez individuals reached $12 \mathrm{~m}$ and are the tallest trees sampled, while the highest absolute DBH $(54.1 \mathrm{~cm})$ was measured in a S. glanduloso-marginata individual (Table 2). The Shannon index was 3.22 nats.ind ${ }^{-1}$. The climax species totaled 143.7 of the VI, while the secondary species and pioneer species summed 85.6 and 48.2, respectively.

The vegetation in zone B has two vertical strata: a lower one that reaches up to $9 \mathrm{~m}$ in height, composed of species such as Cyathea delgadii Sternb., Mollinedia argyrogyna Perkins, Mollinedia boracensis Peixoto and Myrcia pubipetala Miq.; and an upper one, which ranges between 9 and $18 \mathrm{~m}$ height, in which trees with $15 \mathrm{~m}$ or more in height belonged to the Myrcia splendens (Sw.) DC. individuals, Ocotea odorifera (Vell.) Rohwer, Ocotea nunesiana (Vattimo-Gil) Baitello, O. pulchella, Persea willdenovii Kosterm., Pouteria bullata (S.Moore) Beahni, Psychotria vellosiana Benth., Sloanea lasiocoma K. Schum., and Tachigali denudata (Vogel) Oliveira-Filho. This description shows how important the presence of Lauraceae in the canopy is. The three species with the highest coverage dominance were A. triplinervia, $P$. willdenovii and T. denudata, totaling 32.8\%. The highest trees are represented by individuals that reaches up to $18 \mathrm{~m}$ in height and included $O$. odorifera, S. lasiocoma and T. denudata individuals, while the highest DBH $(89.1 \mathrm{~cm})$ was measured in a S. lasiocoma individual (Table 2). The Shannon index was 3.05 nats.ind $^{-1}$. The climax species accounted for lesser of total VI than the secondary species (106.4 and 124.1, respectively), while pioneer species summed only 27.3 .

The vegetation of altimetric zone $\mathrm{C}$ has four vertical strata: the lower one reaches up to $9 \mathrm{~m}$ height, gathering several sciophilous species that compete with sapling trees of the upper stratum, especially Cyathea atrovirens (Langsd. \& Fisch.)
Domin, Guatteria australis A. St.-Hil., Mollinedia schottiana (Spreng.) Perkins, Mollinedia elegans Tul., P. suterella, and Syagrus hoehnei Burret; the second stratum ranges between 9 to $18 \mathrm{~m}$ height and are mainly composed of Aniba viridis Mez, Calyptranthes lucida DC., Guapira opposita (Vell.) Reitz, Inga sessilis (Vell.) Mart. and P. bullata individuals; the third stratum ranging from 18 to $28 \mathrm{~m}$ height is composed of large A. triplinervia, Aspidosperma australe Müll. Arg., Cabralea canjerana (Vell.) Mart., Copaifera trapezifolia Hayne, Cryptocarya aschersoniana Mez, Eugenia copacabanensis Kiaersk., Matayba intermedia Radlk., Nectandra oppositifolia Nees, O. catharinensis, Ocotea nectandrifolia Mez, O. odorifera, Schefflera angustissima (Marchal) Frodin and Posoqueria latifolia (Rudge) Schult. individuals; the fourth and highest stratum (28 to $40 \mathrm{~m}$ height) is formed of emergent trees, such as A. triplinervia, C. aschersoniana, C. trapezifolia, Marlierea reitzii D. Legrand, Myrcia undulata $\mathrm{O}$. Berg, O. catharinensis, and O. nectandrifolia. Three species showed the highest coverage dominance $(O$. catharinensis, C. aschersoniana, and A. triplinervia), totaling $54.6 \%$ of this parameter. The highest DBH $(95.5 \mathrm{~cm})$ was measured on a $40 \mathrm{~m}$-height specimen of $O$. catharinensis (Table 2). When only canopy species were considered, O. catharinensis was also the most abundant in the sapling compartment with 560 ind.ha $^{-1}$. The Shannon index was 3.45 nats.ind $^{-1}$. The climax species accounted for 126.6 of the VI, while the secondary species and the pioneer species, summed 108.2 and 18.0 of VI, respectively.

In the altimetric zone $\mathrm{D}$, vegetation has also four vertical strata: the first reaches up to $9 \mathrm{~m}$ in height and are mainly composed of species such as C. atrovirens, C. delgadii, Endlicheria paniculata (Spreng.) J.F. Macbr., Euterpe edulis Mart., and Garcinia gardneriana (Planch. \& Triana) Zappi; the second stratum varies from 9 to $18 \mathrm{~m}$ height, and the major species are Amaioua intermedia Schult. \& Schult.f., G. opposita, Hirtella hebeclada DC., Mollinedia uleana Perkins, and P. vellosiana; the third stratum ranging from 18 to $28 \mathrm{~m}$ height is similar to forest in zone $\mathrm{C}$ in species composition. A. triplinervia, C. aschersoniana, E. copacabanensis, Heisteria silvianii Schwacke, M. intermedia, M. reitzii, N. oppositifolia, O. nectandrifolia, Protium kleinii Cuatrec., P. bullata, and Vitex polygama Cham. are 
the major species of this stratum; the last and higher stratum varies between 28 to $38 \mathrm{~m}$ in height and is formed of emergent trees such as A. triplinervia, A. australe, C. aschersoniana, C. trapezifolia, O. catharinensis, $P$. kleinii, and Pterocarpus rohrii Vahl. The three species with the highest coverage dominance were $O$. catharinensis, A. triplinervia, and $A$. australe, totaling $35.8 \%$ of this parameter. Two O. catharinensis trees must be distinguished, one with the highest $\mathrm{DBH}(83.4 \mathrm{~cm})$ and other with the highest absolute height (38 m; Table 2). This species was also the most abundant canopy tree among the sapling species, totaling 320 ind.ha $^{-1}$. The Shannon index was 3.64 nats.ind ${ }^{-1}$. Unlike the other areas, here human intervention was detected by the clandestine extraction of peach-palm E. edulis, which may explain the massive presence of individuals in the regeneration strata, and the absence of adults in the arboreal compartment. The climax species totaled 77.0 of the VI, while the secondary and the pioneer species 134.6 and 25.5, respectively.

It is worth mentioning that the average height of the trees tends to increase while the altitude decreases. In this altimetric zone, the mean height was $30 \%$ higher in zone B than in zone A, and $97 \%$ higher in zone $\mathrm{C}$ than in zone $\mathrm{B}$. The same trend was observed for the mean DBH, which was $14 \%$ higher in zone B than in zone A, and $29 \%$ higher in zone $C$ than in zone B. Finally, the basal area recorded for zone A $\left(34.13 \mathrm{~m}^{2}\right.$. ha-1) represents a decrease of $71 \%$ in the same parameter when compared with zone C (58.35 $\mathrm{m}^{2}$.ha-1) (Table 2).

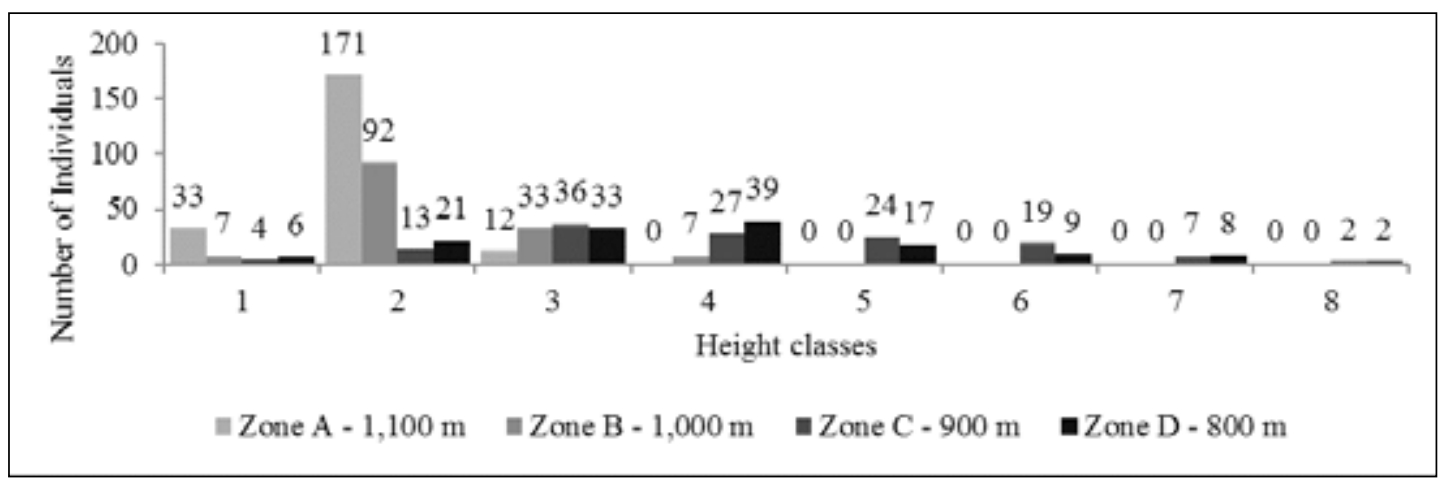

Figure 1. Distribution of the number of individuals per height class in the Montane Atlantic Rain Forest in the Lauráceas State Park, Paraná, in which 1: 1.5-5 m; 2: 5.1-10 m; 3: 10.1-15 m; 4: 15.1-20 m; 5: 20.1-25 m; 6: 25.1-30 m; 7: 30.1-35 $\mathrm{m}$; and 8: 35.1-40 $\mathrm{m}$.

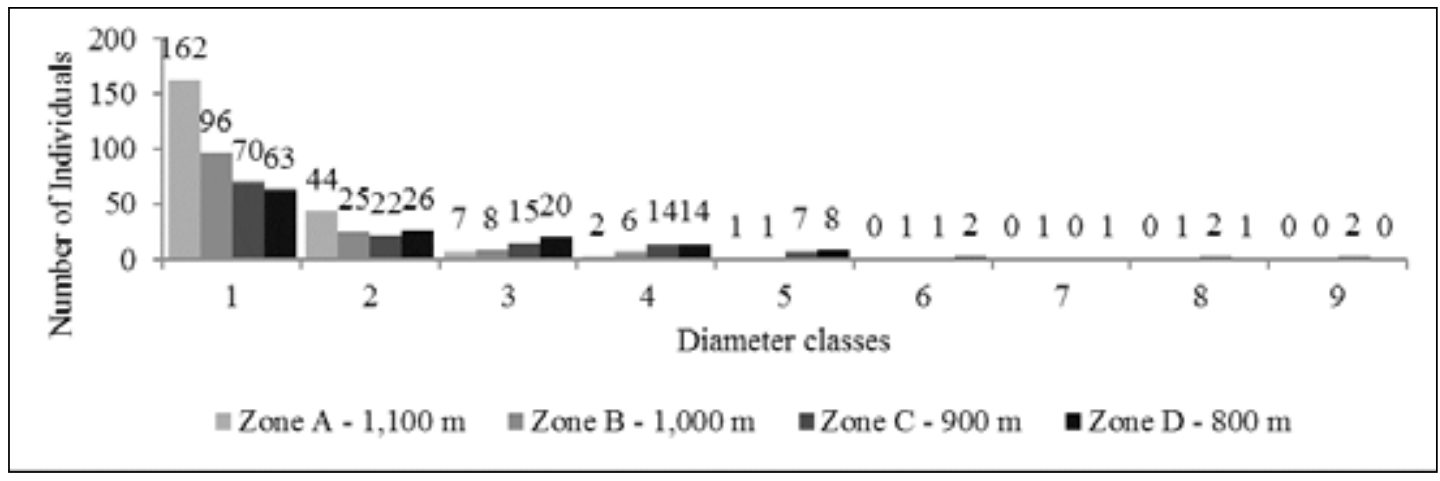

Figure 2. Distribution of the number of individuals per diameter class in the Montane Atlantic Rain Forest in the Lauráceas State Park, Paraná, in which 1: 10-20 cm; 2: 20.1-30 cm; 3: 30.1-40 cm; 4: 40.1-50 cm; 5: 50.1-60 cm; 6: 60.1-70 cm; 7: 70.1-80 cm; 8: 80.1-90 cm; and 9: 90.1-100 cm. 


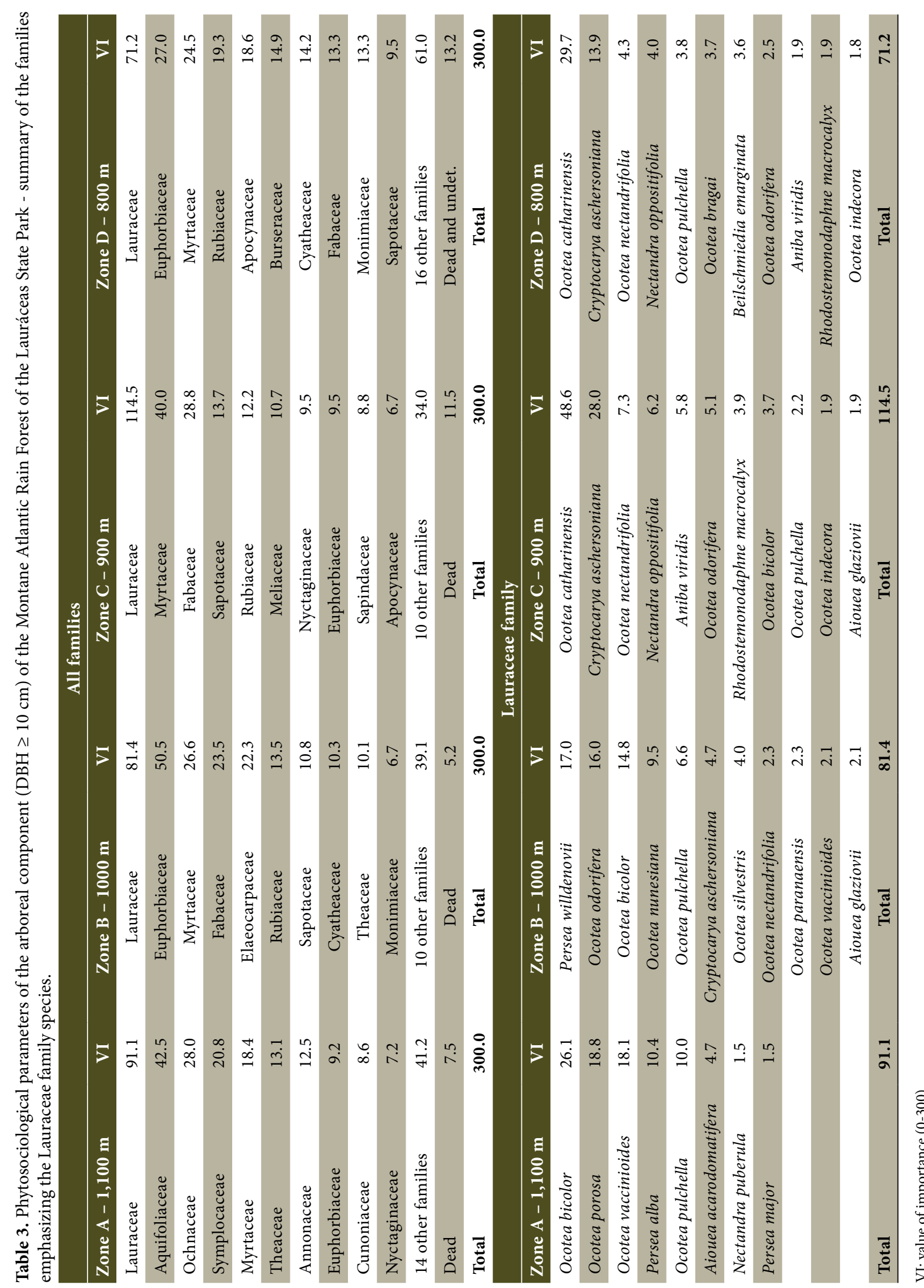


The graphs of the hypsometric distribution (Figure 1) and of the diametric distribution (Figure 2) of the arboreal compartment also show a significant difference between the altimetric zones. The number of individuals sampled was greatest in altimetric zone $\mathrm{A}$, and individuals are concentrated in classes of smaller diameter and height, while in zones $\mathrm{C}$ and $\mathrm{D}$ there are more individuals in the classes with greater diameter and height, but with a lower number of individuals. Contrarily, altimetric zone B seems to represent a transition zone between the first and the last area. Zones $\mathrm{C}$ and $\mathrm{D}$ have 130 trees per hectare with $\mathrm{DBH}>40 \mathrm{~cm}$, and almost half of them are Lauraceae.

The calculation of stem with bark volume in zones $C$ and $\mathrm{D}$ showed O. catharinensis summed $92.70 \mathrm{~m}^{3} \cdot \mathrm{ha}^{-1}$, which represents $25.5 \%$ of the total volume, followed by C. aschersoniana with $38.85 \mathrm{~m}^{3} \cdot \mathrm{ha}^{-1}$ (10.7\%), $A$. triplinervia with $34.06 \mathrm{~m}^{3} \cdot \mathrm{ha}^{-1}$ (9.4\%), A. australe with $20.21 \mathrm{~m}^{3} \cdot \mathrm{ha}^{-1}(5.6 \%)$, and C. trapezifolia with $17.91 \mathrm{~m}^{3}$. $\mathrm{ha}^{-1}(4.9 \%)$. However, the two major Lauraceae species were more expressive in zone $\mathrm{C}$, accounting for nearly half of the commercial volume (49.3\%). In zone $\mathrm{C}, \mathrm{O}$. catharinensis accounts for $119.00 \mathrm{~m}^{3} \cdot \mathrm{ha}^{-1}(33.5 \%)$ and $C$. aschersoniana for $55.87 \mathrm{~m}^{3} \cdot \mathrm{ha}^{-1}$ (15.7\%) (Table 1). The total volume values in zones $A$ and $B$ were significantly lower than in C and D, respectively, totaling $106.83 \mathrm{~m}^{3}$. $\mathrm{ha}^{-1}$ and $143.58 \mathrm{~m}^{3} \cdot \mathrm{ha}^{-1}$ versus $354.93 \mathrm{~m}^{3} \cdot \mathrm{ha}^{-1}$ and $373.28 \mathrm{~m}^{3} \cdot \mathrm{ha}^{-1}$.

An alternation was observed in the main families' VI order according to altitude in the sapling compartment. In zone A, Myrtaceae (55.2), Lauraceae (47.6), and Ochnaceae (47.5) are the main families ordered according to VI values; in zone B, Lauraceae (76.8), Myrtaceae (39.8), and Melastomataceae (29.8); in zone C, Rubiaceae (63.3), Lauraceae (50.4), and Myrtaceae (47.6); and, finally, in zone D, Lauraceae (56.7), Arecaceae (51.2), and Myrtaceae (46.7).

The Montane ARF located between 800 and $1,100 \mathrm{~m}$ of altitude in the $P E L$ have the following five families of major sociological importance: Lauraceae $(\mathrm{VI}=89.6)$, Myrtaceae (27.4), Euphorbiaceae (24.0), Fabaceae (16.8), and Rubiaceae (12.6) in the arboreal compartment (Table 3); and Lauraceae (52.0), Myrtaceae (46.6), Monimiaceae (29.0), Rubiaceae (23.7), and Melastomataceae (22.4) in the regeneration compartment.

The richness of the forest community studied is close to the numbers already known for the Montane
ARF in Paraná, which are 52 families, 101 genera, and 210 species (Scheer \& Blum, 2011). The richness order of the first five families perfectly coincides with those cited by these authors. The families Fabaceae, Lauraceae, Myrtaceae, Melastomataceae, and Rubiaceae are recognized as the richest in the ARF of southern and southeastern Brazil, while the genera Eugenia, Miconia, Myrcia, and Ocotea are always cited as speciesrich families (Oliveira-Filho \& Fontes, 2000; Scheer \& Blum, 2011; Vibrans et al., 2013).

An unusual fact is that Lauraceae surpassed the number of taxa of Myrtaceae. This was recorded only once among four sites surveyed in the Montane ARF in Paraná, in Serra da Baitaca (7 spp./5 spp.) (Roderjan, 1994). The others pointed to a greater species richness of Myrtaceae over Lauraceae, at Serra da Prata (40 spp./12 spp.) (Blum, 2006), at Mananciais da Serra (22/11) (Reginato \& Goldenberg, 2007), and at Serra da Melança (19/8) (Lacerda, 1999). The same pattern occurs in South and Southeastern region of Brazil, where Myrtaceae richness is slightly less than twice the species number of Lauraceae in Montane ARF, such as in the municipalities of Alfredo Wagner, SC, (23/16) (Silva et al., 2013), Morro Grande, SC, (11/7) (Bosa et al., 2015), Cotia, SP, (56/32) (Catharino et al., 2006) and São Luiz do Paraitinga, SP, (57/33) (Padgurschi et al., 2011); or in a lower montane ARF such as in the municipalities of Blumenau, SC, (21/18) (Caglioni et al., 2015), Brusque, SC, (34/19) (Maçaneiro et al., 2015), Siderópolis, SC, (14/9) (Colonetti et al., 2009), Pariquera-Açu, SP, (40/19) (Ivanauskas, 1997) and Cachoeiras de Macacu, RJ (27/14) (Kurtz \& Araújo, 2000). However, this pattern changes in most Submontane ARF areas in southeastern Brazil or in ecotone zones with Seasonal Forests, in which Fabaceae and Rubiaceae families increase their specific richness, surpassing Myrtaceae and/or Lauraceae (Borém \& Oliveira-Filho, 2002; Carvalho et al., 2007; Leite \& Rodrigues, 2008; Pinto Sobrinho et al., 2010; Campos et al., 2011; Gomes et al., 2011).

The predominance of Lauraceae and Myrtaceae is corroborated by studies in Montane ARF in Paraná, with a remarkably small VI sum amplitude (111-117.5) (Lacerda, 1999; Blum, 2006; Reginato \& Goldenberg, 2007), except in the study by Roderjan (1994), who obtained a VI sum of 71.6 for the two families. This can be the result of a sampling range that covers areas with altitudinal range above that of the other studies, which results in addition of taxa typical of high altitude. 
The forest structure in zone A resembles that of two other sites sampled in Serra do Mar in Paraná State. In Serra Gigante (1,000 $\mathrm{m}$ a.s.l.), less than a half of both communities' richness is shared, accumulating a VI of 216 (Scheer et al., 2011) versus 179 in the PEL. In turn, in Serra da Baitaca (1,135-1,250 m a.s.l.) the shared species represents only one-third of total species assembly, accumulating a VI of 106 (Roderjan, 1994) versus 103 in the PEL. Although the Serra Gigante site was considered a cloud forest (upper montane ARF), the authors observed the flora included species frequently found in montane forests, which could be related to the lower altitude of the site when compared with other cloud forest sites. The same trend was observed in zone A.

The forest in zone B resembled the sampled site at 1,000 $\mathrm{m}$ altitude in Serra da Prata (Blum, 2006), but the shared species assembly accumulate different importance values (VI $=68$ in Serra da Prata, versus 148 in the PEL). Although the basal area of $55.53 \mathrm{~m}^{2}$. $\mathrm{ha}^{-1}$ at Serra da Prata has been higher, the canopy height (from 16 to $17 \mathrm{~m})$, mean height $(10.3 \mathrm{~m})$ and average DBH $(20.7 \mathrm{~cm})$ reached values quite similar to those found in zone $\mathrm{B}$.

In turn, zone $\mathrm{C}$ and $\mathrm{D}$ were similar to sites with the same altitude in Serra da Prata (Blum, 2006) with quite similar values of maximum DBH $(96.5 \mathrm{~cm})$ and basal area $\left(54.75 \mathrm{~m}^{2} \cdot \mathrm{ha}^{-1}\right)$, while the maximum height $(23 \mathrm{~m})$, mean height $(12.3 \mathrm{~m})$, and average $\mathrm{DBH}$ $(22.5 \mathrm{~cm})$ values were lower than those determined for zones $\mathrm{C}$ and $\mathrm{D}$.

In general, the results of $P E L$ gradient was compatible with studies conducted in the same altimetric range in the state of Paraná.

Once comparing these results with the gradient studied by Blum (2006), and based on terms he suggested, one can define the vegetation located between 800 and $900 \mathrm{~m}$ in the PEL as a typical Montane ARF and that between 1,000-1,100 $\mathrm{m}$ as a short-stature Montane ARF; thus indicating that this structural tendency seems to be repeated in different areas of Serra do Mar mountain range in Paraná.

When the structural parameters are compared with those established by Brasil (1994a, 1994b), they firstly indicate that the vegetation in altimetric zones $A$ and $B$ could be a forest in middle stage of regeneration. In these zones, the number of strata, the canopy height, and the basal area agreed with the reference values, while the mean height showed lower value, and the mean diameter and the diametric distribution showed higher values. Diversely, evaluating the representation of species ecological groups using VI results, climax species remarkably prevail at $1,100 \mathrm{~m}$ of altitude (although the forest has only one stratum). Secondary species prevail at $1,000 \mathrm{~m}$, with little difference for climax species.

The structural parameters suggests the forest succession stage in the zones $\mathrm{C}$ and $\mathrm{D}$ can be considered in advanced stage of succession, since some parameters such as the number of strata, the canopy height, the basal area, and the mean diameter fits quite well in those established in Brasil (1994a, 1994b). However, the mean height value was slightly lower, and the diametric distribution was slightly higher than the values proposed in Brasil (1994a, 1994b). In the Forest Floristic Inventory of Santa Catarina (Inventário Florístico Florestal de Santa Catarina - IFFSC), four sample units (of numbers 386, 421, 578 and 1,025) at an altitude similar to that of this study site were considered primary forests, therefore being in an advanced stage of succession with basal area ranging from 31.36 to $54.26 \mathrm{~m}^{2}$.ha-1 (Vibrans et al., 2013), values quite similar to those found for zones C and D.

According to Roderjan (1994), the structural and floristic changes in the forest varies in direct proportion to the thickness of the soils, which may explain the variation along the gradient studied, similar to that observed by Blum (2006). Moreover, considering that no register of human intervention in zones $\mathrm{A}$ and $\mathrm{B}$ is found, the best designation for these communities is an advanced successional stage conditioned by limiting environmental factors, which results in a smaller forest compared with zones $\mathrm{C}$ and $\mathrm{D}$.

The forest community of the $P E L$, specifically between 800 and $900 \mathrm{~m}$ a.s.l., in several aspects, resembles those of ARF in the lower and middle parts of the Itajaí valley in Santa Catarina (Klein, 1980). The structural importance of Lauraceae is among the main similarities, given their great abundance and frequency, as well as the dominance of their canopies, representing $27 \%$ of all trees and $44 \%$ of the total canopy cover in the PEL. The major species in the upper stratum in both regions are O. catharinensis, C. aschersoniana, A. triplinervia, 
A. australe, and C. trapezifolia, emphasizing that the first two species aggregated a VI of 60.1 in this study.

Another striking comparison concerns the description of forest slopes with deeper soil and soft undulating relief in the lower and middle parts of the Itajaí valley (Klein, 1980), a topographic description identical to that of forest in zone C. For Klein (1980), this topographic situation allows $O$. catharinensis to express its greatest vitality, often representing between one-third and one-half of wood volume per hectare, while canopy coverage often reaches $40 \%$ to $50 \%$. The author also mentions that this species shows a very balanced vitality in almost all of the vast Itajaí valley, with young and adult individuals capable of maintaining high sociological values. Compared with another species in zone $\mathrm{C}, \mathrm{O}$. catharinensis had the highest values of density, dominance and frequency, which result in a VI of 48.6, nearly one-sixth of the total. It was also the most abundant canopy tree among the saplings. Its relative crown dominance was the highest (31.9\%), and, although somewhat lower than that reported by Klein (1980), it was still relevant considering that it divided the total with 43 other species. Finally, its stem volume represented $33.5 \%$ among all species.

\section{CONCLUSIONS}

At lower altitudes, the community was classified as typical Montane Atlantic Rain Forest, where Ocotea catharinensis is the dominant species followed by Cryptocarya aschersoniana, which very well characterizes a typical Southern Brazilian Ocotietum. At higher altitudes, the community was classified as a shortstature Montane Atlantic Rain Forest, where O. porosa and $O$. vaccinioides have high importance.

Lauraceae is the main family in structural expression and species richness in the Montane Atlantic Rain Forest composition within the "Lauráceas" State Park, in both compartments adults and regeneration. A remarkable aspect is that the lauracean species richness surpassed those of Myrtaceae, somewhat rarely found in southern and southeastern Brazilian forests.

The Lauráceas State Park has remnants of Montane Atlantic Rain Forest in an advanced stage of succession. Its structure indicates that it probably has not undergone logging.

\section{SUBMISSION STATUS}

Received: 23 May, 2017

Accepted: 19 Jan., 2018

\section{CORRESPONDENCE TO}

\section{Marcelo Brotto}

Rua Eng. Ostoja Roguski, 690, CP 1142, Curitiba, PR, Brasil

e-mail: mabrotto@smma.curitiba.pr.gov.br

\section{REFERENCES}

Blum CT. A Floresta Ombrófila Densa na Serra da Prata, Parque Nacional Saint-Hilaire/Lange, PR - Caracterização Florística, Fitossociológica e Ambiental de um Gradiente Altitudinal [dissertation]. Curitiba: Setor de Ciências Agrárias, Universidade Federal do Paraná; 2006.

Blum CT, Roderjan CV. Espécies indicadoras em um gradiente da Floresta Ombrófila Densa na Serra da Prata, Paraná, Brasil. Revista Brasileira de Biociências 2007; 5(Suppl 2): 873-875.

Borém RA, Oliveira-Filho AT. Fitossociologia do estrato arbóreo em uma toposseqüência alterada de Mata Atlântica, no município de Silva Jardim-RJ, Brasil. Revista Árvore 2002; 26(6): 727-742. 10.1590/S010067622002000600009

Bosa DM, Pacheco D, Pasetto MR, Santos R. Florística e estrutura do componente arbóreo de uma Floresta Ombrófila Densa Montana em Santa Catarina, Brasil. Revista Árvore 2015; 39(1): 49-58. 10.1590/010067622015000100005 .

Brasil. Ministério do Meio Ambiente. Conselho Nacional de Meio Ambiente - CONAMA. Resolução CONAMA $n^{\circ}$ 2, de 18 de março de 1994. 1994a [cited 2016 Nov. 29]. Available from: https://bit.ly/2KvZnvv

Brasil. Ministério do Meio Ambiente. Conselho Nacional de Meio Ambiente - CONAMA. Resolução CONAMA $n^{\circ} 4$, de 4 de maio de 1994. 1994b [cited 2016 Nov. 29]. Available from: https://bit.ly/2YN2CHR

Budowski, G. Distribution of tropical American rain forest species in the light of successional processes. Turrialba 1965; 15(1): 40-42.

Campos MCR, Tamashiro JY, Assis MA, Joly CA. Florística e fitossociologia do componente arbóreo da transição Floresta Ombrófila Densa das Terras Baixas - Floresta Ombrófila Densa

Submontana do Núcleo Picinguaba/PESM, Ubatuba, sudeste do Brasil. Biota Neotropica 2011; 11(2): 301-312. 10.1590/S1676-06032011000200030 
Caglioni E, Curcio GR, Uhlmann A, Bonnet A. Estrutura e diversidade do componente arbóreo de Floresta Atlântica no Parque Nacional da Serra do Itajaí, Santa Catarina. Floresta 2015; 45(2): 289-302. 10.5380/rf.v45i2.33499

Carvalho FA, Nascimento MT, Braga JMA. Estrutura e composição florística do estrato arbóreo de um remanescente de Mata Atlântica Submontana no município de Rio Bonito, RJ, Brasil (Mata Rio Vermelho). Revista Árvore 2007; 31(4): 717-730. 10.1590/S0100-67622007000400017

Catharino ELM, Bernacci LC, Franco GADC, Durigan G, Metzger JP. Aspectos da composição e diversidade do componente arbóreo das florestas da Reserva Florestal do Morro Grande, Cotia, SP. Biota Neotropica 2006; 6(2): BN00306022006. 10.1590/S1676-06032006000200004

Colonetti S, Citadini-Zanette V, Martins R, Santos R, Rocha E, Jarenkow JA. Florística e estrutura fitossociológica em floresta ombrófila densa submontana na barragem do rio São Bento, Siderópolis, Estado de Santa Catarina. Acta Scientiarum: Biological Sciences 2009; 31(4): 397-405. 10.4025/actascibiolsci.v31i4.3345

Gomes JAMA, Bernacci LC, Joly CA. Diferenças florísticas e estruturais entre duas cotas altiduninais da Floresta Ombrófila Densa Submontana Atlântica, do Parque Estadual da Serra do Mar, município de Ubatuba/SP, Brasil. Biota Neotropica 2011; 11(2): 123-137. 10.1590/ S1676-06032011000200013

Ivanauskas NM. Caracterização Florística e Fisionômica da Floresta Atlântica sobre a Formação PariqueraAçu, na Zona da Morraria Costeira do Estado de São Paulo [dissertation]. Campinas: Instituto de Biologia, Universidade Estadual de Campinas; 1997.

Klein RM. Ecologia da flora e vegetação do Vale do Itajaí. Sellowia 1980; 32: 165-389.

Klein RM. Aspectos dinâmicos da vegetação do sul do Brasil. Sellowia 1984; 36: 5-54.

Kottek M, Grieser J, Beck C, Rudolf B, Rubel F. World map of the Köppen-Geiger climate classification updated. Meteorologische Zeitschrift 2006; 15(3): 259263. 10.1127/0941-2948/2006/0130

Kurtz BC, Araújo DSD. Composição florística e estrutura do componente arbóreo de um trecho de Mata Atlântica na Estação Ecológica Estadual do Paraíso, Cachoeiras de Macacu, Rio de Janeiro, Brasil. Rodriguésia 2000; 51(7879): 69-112. 10.1590/2175-7860200051787903

Lacerda AEB. Levantamento florístico e estrutural de vegetação secundária em área de contato da Floresta Ombrófila Densa e Mista, PR [dissertation]. Curitiba: Setor de Ciências Biológicas, Universidade Federal do Paraná, Curitiba; 1999.

Leite EC, Rodrigues RR. Fitossociologia e caracterização sucessional de um fragmento de Floresta Estacional Semidecidual no sudeste do Brasil. Revista Árvore 2008; 32(3): 583-595. 10.1590/S0100-67622008000300019
Maçaneiro JP, Seubert RC, Schorn LA. Fitossociologia de uma Floresta Pluvial Subtropical primária no sul do Brasil. Floresta 2015; 45(3): 555-566. 10.5380/rf.v45i3.38157

Magurran AE. Ecological diversity and its measurement. Princeton: Princeton University Press; 1988.

Mueller-Dombois D, Ellenberg H. Aims and methods of vegetation ecology. New York: John Wiley \& Sons; 1974.

Oliveira-Filho AT, Fontes MAL. Patterns of floristic differentiation among Atlantic Forests in Southeastern Brazil and the influence of climate. Biotropica 2000; 32(4b): 793-810. 10.1111/j.1744-7429.2000.tb00619.x

Padgurschi MCG, Pereira LS, Tamashiro JY, Joly CA. Composição e similaridade florística entre duas áreas de Floresta Atlântica Montana, São Paulo, Brasil. Biota Neotropica 2011; 11(2): 139-152. 10.1590/S167606032011000200014

Paraná. Secretaria de Meio Ambiente e Recursos Hídricos. Plano de manejo do Parque Estadual das Lauráceas. Curitiba: Instituto Ambiental do Paraná; 2002.

Pinto Sobrinho FA, Christo AG, Guedes-Bruni RR. Fitossociologia do componente arbóreo num remanescentes de Floresta Ombrófila Densa Submontana limítrofe à Reserva Biológica do Tinguá, Rio de Janeiro. Floresta 2010; 4(1): 111-124. 10.5380/rf.v40i1.17103

Reginato M, Goldenberg R. Análise florística, estrutural e fitogeográfica da vegetação em região de transição entre as Florestas Ombrófilas Mista e Densa Montana, Piraquara, Paraná, Brasil. Hoehnea 2007; 34(3): 349-364. 10.1590/ S2236-89062007000300006

Roderjan CV. O gradiente da Floresta Ombrófila Densa no Morro do Anhangava, Quatro Barras, PR - aspectos climáticos, pedológicos e fitossociológicos [thesis]. Curitiba: Setor de Ciências Agrárias, Universidade Federal do Paraná; 1994.

Scheer MB, Blum CT. Arboreal diversity of the Atlantic Forest of Southern Brazil: from the beach ridges to the Paraná river. In: Grillo O, Venora G. The dynamical processes of biodiversity: case studies of evolution and spatial distribution. London: IntechOpen; 2011.

Scheer MB, Mocochinski AY, Roderjan CV. Estrutura arbórea da Floresta Ombrófila Densa Altomontana de serras do sul do Brasil. Acta Botânica Brasilica 2011; 25(4): 735-750. 10.1590/S0102-33062011000400002

Silva AC, Higuchi P, Negrini M, Grudtner A, Zech DF. Caracterização fitossociológica e fitogeográfica de um trecho de floresta ciliar em Alfredo Wagner, SC, como subsídio para restauração ecológica. Ciência Florestal 2013; 23(4): 579-593. 10.5902/1980509812342

Vibrans AC, Sevegnani L, Gasper AL, Lingner DV. Inventário florístico florestal de Santa Catarina: Floresta Ombrófila Densa. Blumenau: Edifurb; 2013. v. 4. 